\title{
Secondary School Students' Metaphorical Perceptions of the Concept of English
}

\author{
Tuğba Küçüktamer
}

\begin{abstract}
The purpose of the present research is defining secondary school students' metaphorical perceptions of the concept of English. The total of 160 secondary school $7^{\text {th }}$ grade students, who studied at 4 different schools in Konya in 2017-2018 academic year participated in the present research. The participants were provided with the "Secondary School Students' Metaphoric Perceptions of the Concept of English Questionnaire" developed by the researcher, and were asked to complete the sentence, "English is like .... for me, because .....". Obtained data were analysed through content analysis. Obtained findings are presented respectively in tables and figures in the findings part of the study. According to the findings, conceptual categories; "job guarantee $(21 \%)$ ", "connection to the world (18\%)", "wealth (11\%)" and "meaningless (9\%)" were formed based on the source and reason of the most frequently formed metaphors by the students. Additionally, the most frequently used metaphors were "game" and "job".
\end{abstract}

Key Words: English, Secondary School, Metaphor. 
